\title{
Distribution of HLA-B27 subtypes in patients with ankylosing spondylitis: the disease is associated with a common determinant of the various B27 molecules
}

\author{
B S BREUR-VRIESENDORP, ${ }^{1}$ A J DEKKER-SAEYS, ${ }^{2}$ AND P IVANYI \\ From the ${ }^{1}$ Central Laboratory of the Netherlands Red Cross Blood Transfusion Service and Laboratory for \\ Experimental and Clinical Immunology, University of Amsterdam; and ${ }^{2}$ the Jan van Breemen Institute, \\ Amsterdam, The Netherlands
}

SUMMARY HLA-B27 subtypes can be defined by cellular, serological, and biochemical techniques. The seven subtypes ${ }^{49}$ so far identified represent structural variants of B27 with limited variations in the amino acid sequence of the B27 molecule. The routinely typed B27 'antigen' remains a common (shared, public) determinant present on various B27 molecules. The distribution of the subtypes varies strongly among different ethnic groups and they occur in different linkage disequilibria. ${ }^{4}$ In the healthy Dutch population only two subtypes were found: B27W (B27-1, B27M2+) (90\%) and B27K (B27.2, B27M2-) (10\%). A similar distribution of B27 subtypes was observed in 91 unrelated Dutch patients with ankylosing spondylitis (AS)-namely, 92\% B27W and 8\% B27K. In Oriental populations the subtype distribution is quite different: B27W occurs in less than $50 \%$, whereas more than $50 \%$ individuals are of the B27C and B27D subtypes. Preliminary data indicate that the distribution of subtypes in healthy and diseased Oriental individuals is similar. These results suggest that the B27 and disease (AS) association is not correlated with the structural variations of one of the B27 subtypes, but with a common B27 determinant shared by various B27 subtypes. Consequently, the disease is older than the B27 variants. Further studies on disease and subtype distribution in various ethnic groups might contribute to a better understanding of the origin of both.

Key words: cytotoxic T lymphocytes.

The association between HLA-B27 and ankylosing spondylitis (AS), the HLA and disease association with the highest relative risk so far discovered, has been observed in various racial groups. ${ }^{1}$ HLA-B27 is found in about $96 \%$ of patients with AS, but occurs in only $8 \%$ of the normal healthy Caucasian population.

Since the discovery of HLA-B27 subtypes with monoclonal antibodies $(\mathrm{Mab})^{2}$ and cytotoxic $\mathrm{T}$ lymphocytes $(\mathrm{CTL})^{34}$ we have studied the role of the B27 subtypes in the association with AS.

Our results indicate that the disease susceptibility is not correlated with any of the B27 subtypes, but rather with a common determinant present on the variant forms of B27. Further studies of patients

Accepted for publication 10 November 1986.

Correspondence to Dr P Ivanyi, c/o Publication Sccretariat, Central Laboratory of the Netherlands Red Cross Blood Transfusion Service, PO Box 9406, 1006 AK Amsterdam, The Netherlands. with different ethnic origins are required to elaborate this finding.

\section{Patients and methods}

PATIENTS

Patients with AS in this study all satisfied the New York criteria of definite diagnosis of AS (sacroiliitis grade $3-4) .{ }^{5}$ More than $90 \%$ of the patients presented with, besides sacroiliitis, abnormalities of the spinal column, i.e., clear overbridging syndesmophytes at various levels up to a complete bamboo spine. They could all be classified as having the classical form of AS, with age of onset less than 20 years and severely affected sacroiliac joints and spinal column. None of the patients had ulcerative colitis, Crohn's disease, or psoriasis.

Of 91 unrelated Dutch Caucasian AS patients, 63 were male and 28 female. Preliminary results indicated that the B27K subtype occurred more 
Table 1 Generation of HLA-B27 subtype specific CTL using selected responder and stimulator pairs

\begin{tabular}{|c|c|c|c|c|c|c|}
\hline \multirow{2}{*}{$\begin{array}{l}\text { Designation } \\
\text { of CTL }\end{array}$} & \multicolumn{2}{|c|}{ Responder } & \multicolumn{2}{|c|}{ Stimulator } & \multirow{2}{*}{$\begin{array}{l}\text { Specificity } \\
\text { of } C T L\end{array}$} & \multirow{2}{*}{$\begin{array}{l}{ }^{5 l} \mathrm{Cr} \\
\text { release }^{*}(\%)\end{array}$} \\
\hline & $H L A-A$ & $-B$ & $H L A-A$ & $-B$ & & \\
\hline W1 & A2 , 11 & $\mathrm{~B} 27 \mathrm{~K}, 35$ & A2 , 11 & B27W, 35 & B27W & 41 \\
\hline W2 & $\mathrm{A} 2,3$ & B27K, 35 & A3, 3 & B27W, 35 & $\mathrm{~B} 27 \mathrm{~W}$ & 47 \\
\hline W3 & $\mathrm{A} 2,3$ & $\mathrm{~B} 27 \mathrm{~K}, 35$ & $\mathrm{~A} 2,3$ & B27W, 35 & $\mathrm{~B} 27 \mathrm{~W}$ & 29 \\
\hline $\mathrm{K} 1$ & A2 , 11 & B27W,35 & A2 , 11 & B27K, 35 & B27K & 54 \\
\hline $\mathrm{K} 2$ & A2 , 28 & $\mathrm{B} 27 \mathrm{~W}, 7$ & A2 ,28 & B27K, 27K & B27K & 59 \\
\hline $\mathrm{K} 3$ & $\mathrm{~A} 2,3$ & B27W, 35 & $\mathrm{~A} 2,3$ & B27K, 35 & B27K & 52 \\
\hline $\mathrm{C} 1$ & $\mathrm{~A} 24,11$ & $\mathrm{~B} 27 \mathrm{~W}, 35$ & A24,11 & $\mathrm{B} 27 \mathrm{C}, 35$ & $\mathrm{~B} 27 \mathrm{C} / \mathrm{D}$ & 31 \\
\hline $\mathrm{C} 2$ & $\mathrm{~A} 1,2$ & $\mathrm{~B} 27 \mathrm{~W}, 8$ & $\mathrm{~A} 1,2$ & $\mathrm{~B} 27 \mathrm{C}, 8$ & $\mathrm{~B} 27 \mathrm{C} / \mathrm{D}$ & 48 \\
\hline $\mathrm{C} 3$ & A2 , 11 & B27W,51 & A 11,11 & B27C, 27D & $\mathrm{B} 27 \mathrm{C} / \mathrm{D}$ & 66 \\
\hline
\end{tabular}

*The specific lysis on stimulator target cells at an effector to target ratio of 10:1.

frequently in female AS patients, and the number of female $\mathrm{B} 27^{+}$classical AS patients with abnormalities of the spinal column was increased. Ten patients with AS were of Oriental (Indonesian and Chinese) origin. The controls were healthy blood donors.

The HLA-B27 ${ }^{+} \mathrm{AS}^{+}$patients and $\mathrm{B} 27^{+} \mathrm{AS}^{-}$ controls were HLA-A, B, C, and DR phenotyped by routine HLA serological typing. The B27 subtypes were determined in a standard, cell mediated lympholysis (CML) assay with subtype specific alloimmune CTL, as described. ${ }^{34}$

DETERMINATION OF B27 SUBTYPES BY CYTOTOXIC T CELLS (TYPING OF CTL)

Generation of HLA-B27 subtype specific CTL and the CML assay have been described in detail previously. ${ }^{346} \mathrm{CTL}$ were generated using selected responder cell and stimulator cell combinations as listed in Table 1.

Effector cells and ${ }^{51} \mathrm{Cr}$ labelled target cells were incubated for eight hours at $37^{\circ} \mathrm{C}$. Supernatants were harvested and the ${ }^{51} \mathrm{Cr}$ release was determined. The cytotoxicity was calculated by the formula:

$$
\frac{\mathrm{cpm} \text { exp. }-\mathrm{cpm} \text { in medium }}{\mathrm{cpm} 1 \% \text { saponin }-\mathrm{cpm} \text { in medium }} \times 100
$$

Experiments were repeated at least twice at three effector to target ratios.

BIOCHEMICAL ANALYSIS

Procedures for the one dimensional isoelectric focusing (1D-IEF) of HLA class 1 antigens have been described elsewhere. ${ }^{7}$ In brief, cells were metabolically labelled with $\left[{ }^{35} \mathrm{~S}\right]$ methionine for six hours. Cell lysates were prepared with the detergent Triton X-114. After preclearing with normal rabbit serum and staphylococcal protein A, HLA-A, B, and $C$ antigens were precipitated with the Mab W6/32 as described. Immunoprecipitates were digested with neuraminidase. Gel electrophores was carried out by the horizontal slab gel techniques Detection of radioactive products was performed by fluorography.

\section{Results}

The subtypes of $\mathrm{B} 27^{+}$cells were identified with $\cdot \mathrm{a}$ series of B27W, B27K, and B27C/D subtype speciff CTL (see Table 1). According to the reactivit patterns of the typing CTL on $\mathrm{B} 27^{+}$cells, we could identify B27W, B27K, and B27C or B27D subtyp positive individuals. ${ }^{4}$

In parallel, and mainly to distinguish the B27 from the B27D subtype, 1D-IEF gel electrophores was performed with cells from selected $\mathrm{B} 27^{+}$ind viduals. The cell lysates were immunoprecipitated with the Mab W6/32, which recognises a monomots phic determinant of the HLA-A, B, and C heary chains complexed with $\beta_{2}$ microglobulin. Fol

Table 2 Distribution of HLA-B27 subtypes in Dutch 윽 control population and patients with ankylosing spondylitis and in a limited number of Oriental individuals

\begin{tabular}{|c|c|c|c|c|}
\hline & \multirow{2}{*}{$\begin{array}{l}\text { Total } \\
n\end{array}$} & $W$ & $K$ & $C / D$ ఠ \\
\hline & & $n \quad(\%)$ & $n \quad(\%)$ & $n$ (\% \\
\hline \multicolumn{5}{|l|}{ Dutch } \\
\hline Control & 70 & $63(90)$ & $7(10)$ & 0 \\
\hline Ankylosing spondylitis* & 91 & $85(93)$ & $7(8)$ & c \\
\hline Total & 161 & $148(92)$ & 14 ( 9) & 0 \\
\hline \multicolumn{5}{|l|}{ Oriental } \\
\hline Control & 11 & $5(45)$ & $0(0)$ & $6(5 \overline{9})$ \\
\hline Ankylosing spondylitis & 10 & $4(40)$ & $1(10)$ & $5(5 \vec{D}$ \\
\hline Total & 21 & $9(43)$ & $1(5)$ & $11(5 \%$ \\
\hline
\end{tabular}

*Sixty three men and 28 women, one patient with AS was B27 B27K. 
distinct isoelectric focusing patterns of B27 heavy chains $(\mathrm{W}, \mathrm{K}, \mathrm{C}, \mathrm{D})$ were identified. ${ }^{4} 7$

In this study we examined the B27 subtypes from 91 unrelated Dutch Caucasian $\mathrm{B} 27^{+}$AS patients, 10 Oriental $\mathrm{B} 27^{+}$AS patients, and $81 \mathrm{~B}^{2} 7^{+}$control individuals. The results (summarised in Table 2) show an equal distribution of the B27W and B27K subtypes in the Dutch AS patients and the controls. No apparent preference was observed for one of the B27 subtypes and the disease susceptibility in the limited number of Oriental individuals.

The B27W subtype is prevalent in Caucasians, with a frequency of about $90 \% \mathrm{~B} 27 \mathrm{~W}$ and $10 \%$ $\mathrm{B} 27 \mathrm{~K}$. None of the Caucasian cells was B27C or. B27D. In contrast, subtypes B27C and B27D were observed in more than $50 \%$ of the cells of Oriental origin.

\section{Discussion}

The results of the present study again emphasise that, although B27 remains one of the best defined HLA antigens as detected by highly selected conventional alloimmune antisera, ${ }^{8}$ a surprisingly high number of HLA-B27 subtypes exist. ${ }^{49}$ These subtypes, which can be identified by cellular, ${ }^{3410}$ serological, $^{2} 1112$ and biochemical ${ }^{79}$ (1D-IEF) techniques, occur in various linkage disequilibria. ${ }^{4}$ The distribution of the subtypes in various ethnic groups is clearly different. ${ }^{49} 1314$

The complete amino acid sequence of four HLAB27 subtypes has been described, and the positions in which the molecules differ have been established. ${ }^{15-19}$ Various HLA-B27 genes have been isolated and sequenced. ${ }^{20-22}$ Thus B27 is not only the HLA antigen with the highest disease association, but also the most studied and best understood.

HLA-B27 does not exist as a genetic entity or as the product of one B27 allele. What is routinely typed and designated as HLA-B27, is a family of (at least seven) closely related B27 molecules (variants/ mutants). The B27 subtypes are structural variants occurring along about 338 amino acids of a $45 \mathrm{kD}$ molecular mass polypeptide chain. The variations are due to point mutations, events similar to gene conversions, or other chromosomal rearrangements, mainly in the first or second domain, or both, of the B27 molecule. ${ }^{12} 18-2123$

The conventional anti-B27 sera that are routinely used to type the antigen B27 in HLA laboratories recognise a common B27 determinant present on the various B27 molecules. Interestingly, it is this common (public) determinant and not one of the subtype specific (private) determinants of B27 which is associated with AS. This is at variance with the conclusion from preliminary studies by Grumet et al. ${ }^{12} 14$ They suggested that B27 variants might be disease related, especially in Orientals.

Although a relatively high number of Dutch patients and controls were tested, the data are still preliminary, particularly for other populations. Further studies on the distribution of B27 subtypes and the association with AS in various ethnic groups are needed before general conclusions can be made. Moreover, the possible role of the B27 subtypes in other disease associations, including some reactive arthropathies, can now be studied. Such studies will contribute to a better understanding of disease associations and the evolutionary aspect of HLA (B27) polymorphism.

The combined data indicate that the variations of the B27 molecule are of rather recent origin. ${ }^{1820} 21$ Since the association of AS and HLA-B27 has been confirmed in patients with various racial backgrounds ${ }^{1}$ the disease (AS) appears to be older than the origin of the $\mathrm{B} 27$ variants.

We thank all patients who volunteered to participate in this study and the late Bert Huis for excellent technical assistance. The study was financially supported in part by the Netherlands League against Rheumatism and in part by the Dutch Kidney Foundation.

\section{References}

1 Tiwari J L. Terasaki P I. HLA and disease associations. New York/Berlin/Heidelberg/Tokyo: Springer. 1985.

2 Grumet F C. Fendly B M. Fish L. Foung S, Engleman E G. Monoclonal antibody (BM27M2) subdividing HLA-B27. Hum Immunol 1982; 5: 61-72.

3 Breuning M H. Lucas C J. Breur B S. et al. Subtypes of HLAB27 detected by cytotoxic T lymphocytes and their role in selfrecognition. Hum Immunol 1982: 5: 259-68.

4 Breur-Vriesendorp B S. Neefjes J J C. Huis B, van Seventer G A. Ploegh H L. Ivanyi P. Identification of new HLA-B27 subtypes (B27C and B27D) prevalent in Oriental populations. Hum Immunol 1986; 16: 163-8.

5 Bennet P H. Burch T A. New diagnostic criteria. New York symposium on population studies in rheumatic diseases. Bull Rheum Dis 1967: 17: 453-8.

6 Breuning M H. Breur B S. Engelsma M Y. Huis B. Ivanyi P. Specificity of anti-HLA-B27 cytotoxic T lymphocytes. Tissue Antigens 1983: 22: 267-82.

7 Neefjes J J, Breur-Vriesendorp B S, van Seventer G A, Ivanyi $\mathrm{P}$, Ploegh $\mathrm{H}$ L. An improved biochemical method for the analysis of polymorphism of HLA class-1 antigens. Definition of new HLA class-1 subtypes. Hum Immunol 1986; 16: 169-81.

8 Breur B S, Ivanyi P. The definition of HLA-B27 by conventional sera of the 9th workshop. In: Albert E D, et al, eds. Histocompatibility testing 1984. Berlin: Springer, 1984: 144.

9 Choo S Y. Antonelli P. Nisperos B. Nepom G T, Hansen J A. Six variants of HLA-B27 identified by isoclectric focusing. Immunogenetics 1986: 23: 24-9.

10 Toubert A. Gomard E. Grumet F C. Amor B, Miller J Y. Levy J P. Identification of several functional subgroups of HLA-B27 by restriction of the activity of antiviral T-killer lymphocytes. Immunogenetics 1984: 20: 513-25.

11 de Waal L P. Lieder J, de Lange G G. Huis B. Melief C J M. Ivanyi P. B27 subtypes. In: Albert E D, et al, eds. Histocompatibility testing 1984. Berlin. Springer. 1984: 418.

12 Turek P J. Grumet F C. Engleman E G. Molecular variants of 
the HLA-B27 antigen in healthy individuals and patients with spondyloarthropathies. Immunol Rev 1985; 86: 71-91.

13 Breur-Vriesendorp B S, Huis B. Dekker A J. Breuning M H. Ivanyi P. Subtypes of antigen HLA-B27 (B27W and B27K) defined by cytotoxic $T$ lvmphocytes: identification of a third subtype (B27C) prevalent in Oriental populations. In: Ziff M. Cohen S, eds. Proceedings of an international conference on the spondyloarthropathies. New York: Raven, 1985.

14 Grumet F C. Calin A. Engleman E G. Fish L. Foung S K H. Studies of HLA-B27 using monoclonal antibodies: ethnic and disease associated variants. In: Ziff M. Cohen S, eds. Proceedings of an international conference on the spondyloarthropathies. New York: Raven. 1985

15 Ezquerra A. Bragado R. Vega M A. Strominger J L. Woody J. López de Castro J A. Primary structure of papain-solubilized human histocompatibility antigen HLA-B27. Biochemistry 1985: 24: 1733-44.

16 Vega M A. Ezquerra A. Rojo S, Aparicio P. Bragado R. López de Castro J A. Structural analysis of an HLA-B27 functional variant: identification of residues that contribute to the specificity of recognition by cytolytic T lymphocytes. Proc Natl Acad Sci USA 1985; 82: 7394-8.

17 Vega M A. Wallace L. Rojo S. Bragado R. Aparicio P. López de Castro $\mathbf{J}$ A. Delincation of functional sites in HLA-B27 antigens. Molecular analysis of HLA-B27 variant Wewak defined by cytolytic $\mathrm{T}$ lymphocytes. J Immunol 1985; 135 3323-32.

18 Vega M A, Bragado R, Ivanyi P. Peláez J L, López de Castrơ J A. Molecular analysis of a functional subtype of HLA-B27 A possible evolutionary pathway for HLA-B27 polymorphism? $J$ Immunol (in press).

19 Choo S Y, Seyfried C, Hansen J A, Nepom G T. Tryptie peptide mapping identifies structural heterogeneity among si $\$$ variants of HLA-B27. Immunogenetics 1986; 23: 409-12.

20 Szöts H, Riethmüller G, Weiss E. Meo T. Complete sequencể of HLA-B27 cDNA identified through the characterization of structural markers unique to the HLA-A-, -B- and -C-allelic series. Proc Natl Acad Sci USA 1986; 83: 1428-32.

21 Seemann G H A. Rein R S. Brown C S, Ploegh H L. Gen W conversion generates polymorphism in human class-1 geneș $E M B O J$ 1986; 5: 547-52.

22 Coppin H L. McDevitt H O. Absence of polymorphisin between HLA-B27 genomic exon sequences isolated frorT normal donors and ankylosing spondylitis patients. J Immun 1986; 137: 2168-72.

23 López de Castro J A, Barbosa J A, Krangel M S, Biro P ACW Strominger J L. Structural analysis of the functional sites $\$$ class-1 HLA antigens. Immunol Rev 1985; 84: 217-36. 